\title{
Angiogenesis in old-aged subjects after ischemic stroke: a cautionary note for investigators
}

\author{
Journal of Angiogenesis Research 2:26 I DOI: 10.1186/2040-2384-2-26 I C Li et al.; licensee \\ Publiverse Online S.R.L. 2010 \\ Received: 24 Aug 2010 | Accepted: 26 Aug 2010 | Published: 26 Aug 2010 \\ Petcu Eugen B ${ }^{@}$, Smith Robert A, Miroiu Rodica I, Opris Maria M \\ ${ }^{+}$Contributed equally ${ }^{@}$ Corresponding author
}

\begin{abstract}
Angiogenesis represents a form of neovascularisation of exceptional importance in numerous pathological conditions including stroke. In this context it is directly related to neuroregeneration which is seen in close proximity. However, numerous experimental data have been drawn from studies that have ignored the age criterion. This is extremely important as angiogenesis is different in young versus old subjects.

Extrapolating data obtained from studies performed in young subjects or "in vitro" to old-age patients could lead to inexact conclusions since the dynamics of angiogenesis is age-dependent.

The current review covers the key features of brain senescence including morphological and functional changes related to the brain parenchyma, its vascular network and blood flow which could possibly influence the process of angiogenesis. This is followed by a description of post-stroke angiogenesis and its relationship to neuroregeneration and its modulation by vascular endothelial growth factor (VEGF) and insulin-like growth factor 1 (IGF 1), the most important factors active in old brain after ischemic injury.
\end{abstract}

\section{Introduction}

Neovascularization represents a crucial phenomenon of paramount importance for the clinical outcome in various pathological conditions including cancer, myocardial infarction and cerebral stroke. Until not too long ago, it was thought that CNS damage induced by stroke is associated with irreversible tissue damage. However, recently, experimental data indicates that this is not the case and neuroregeneration is observed after stroke [ 1,2]. Interestingly, it appears that post-stroke neuroregeneration depends significantly on neovascularization which is encountered in several flavors: vasculogenesis, angiogenesis and arteriogenesis [3]. Vasculogenesis represents the embryological development of the blood vessels from angioblastic precursors and it has been recently described in patients after stroke [4]. Although, the extent to which vasculogenesis modulates post-stroke neuroregeneration is not known, the link between this process and angiogenesis is represented by VEGF and its receptor, which modulate transformation of immature precursor structures into mature capillaries [ 5]. Arteriogenesis is the growth of collateral arteries from pre-existing arterioles after blockage of the main artery. Compared with angiogenesis it does not require a hypoxic environment, and is typically activated by increased pressure and stress, such as that caused by occluded and partially occluded vessels [ 6]. The contribution of this process to neuroregeneration is unknown, however, numerous studies have reported that angiogenesis or formation of new capillaries from pre-existent vessels is closely related to neuroregeneration. After stroke, primordial cells capable to differentiate into functional neurons have been identified in the immediate vicinity of newly formed capillaries [7]. Therefore, it was claimed that this process can be regarded as a neurorestorative event promoting formation of new neurons from adult brain's own neural stem cells (NSC) [ 8,9]. Although factors such as matrix metalloproteinase-2 (MMP-2), matrix metalloproteinase-9 (MMP-9), tissue inhibitor of matrix metalloproteinase 1 (TIMP-1), Hepatocyte growth factor (HGFalpha), monocyte chemo-attractant protein 1 (MCP-1) are increased after ischemic stroke the most 
important seems to be VEGF and its receptor which are increased in the periphery of the ischemic zone at 3 hours after stroke $[10,11]$.

Although, a great deal of research has been performed, it seems that there are significant differences in the angiogenesis encountered in old subjects compared with young ones, including the extent of this process and the factors that may modulate it during different developmental stages. However, since angiogenesis depends on the pre-existing vascular network it is very important to understand if there is any relationship between what is happening with the brain per se and its cerebral blood vessels during senescence and the extent and/or modulation of post-stroke angiogenesis in this context.

The current review will highlight the most salient points related to the senescent brain and its vasculature, and then based on the published data we will review the factors which unequivocally modulate angiogenesis only in elderly subjects. This is necessary since ischemic stroke is mostly described in old age and extrapolating results obtained "in vitro" or from young subjects could lead to erroneous conclusions.

\section{CNS aging process: pivotal points}

Normal aging is associated with a cognitive decline and understanding the related mechanisms remains a central challenge in neuroscience. Moreover, it is currently poorly understood how the CNS morphological changes associated with old age would affect the vascular network and ultimately poststroke angiogenesis.

Morphological and physiological studies have tried to explain the decline in cognitive function associated with old age based on anatomical changes. More than fifty years ago, it was suggested that weight reduction in the senescent brain could be explained by a significant reduction in the neurons [12]. Recently, MRI studies conducted in healthy volunteers have revealed that brain weight loss may affect with predilection only some regions of the brain such as hippocampus or the prefrontal, frontal or enthorinal cortex and the loss of white matter is greater than the decrease in grey matter [ 13, 14]. Other authors have recorded a reduction of the whole limbic system grey matter in healthy elderly [ 15]. Between 30 and 90 years of age, there is an overall decrease in weight of $14 \%$ recorded in the cerebral cortex associated with a $35 \%$ reduction in the hippocampus, and a $26 \%$ weight loss in the cerebral white matter [ 13]. However, it is still debatable if the changes seen in hippocampus are related to "normal" senescence as other studies have suggested that cell death and a decline in weight occurring in this region is not normally observed [ 16,17$]$.

Studies in mice have indicated that aging may reduce both overall neural cell proliferation as well as the developmental pathway followed by proliferating cells in the brain, leading to fewer mature neurons replacing those lost to age or damage [ 18].

Regarding the vasculature, although earlier studies have shown no difference or even an increase in the cerebral arteriolar network in old versus young subjects, the current opinion is that old age is characterized by a significant decrease in density of vessels supplying the cerebral cortex compared with young controls as well as morphological changes of the remaining vessels [ 19-22]. More recently, Amenta et al (1995) have reported that the capillary network is significantly decreased in Wistar rats of 27 and 24 months versus young 12 month-old subjects [23]. Therefore, it seems unequivocal that aging is associated with a significant decrease in superficial cortical vessels which according to some authors, could be induced by an age-related decrease in growth hormone and insulin-like growth factor 1 [ 21]. However, growth hormone treatment administered to aged animals for 6 weeks did not alter hippocampal capillary density and did not ameliorate the age-related deficit in angiogenesis. Therefore, the exact relationship between growth hormone and angiogenesis remains to be elucidated. However, aged animals demonstrate a significant impairment in hypoxia-induced capillary angiogenesis compared to young animals [24]. Regarding the structural alterations of the vessels, significant aging-related microvascular degeneration was encountered especially in the periventricular white matter [25]. Also, in elderly rat subjects there is a decrease in smooth muscle and elastin in parallel with an increase in collagens which impair distension [ 26]. Senescent arterioles present with alterations in capillary endothelial cells including a thickened basement membrane, abnormal inclusions and abnormalities of the astrocytic endfeet [ 27-29]. However, the mechanism behind these changes remains poorly understood although it is accepted that these ultrastructural alterations could lead to a small leakage of blood in the parenchyma [ 30]. Regarding the cerebral blood flow in old-age, recent data suggests that it decreases with advancing age [ $31,32]$. Previous studies have shown a direct correlation between cerebral blood flow and vascular density [33]. It seems that cerebral blood flow is modulated by circulating norepinephrine, NO and sympathetic noradrenergic innervations of cerebral arteries. The young subjects are characterized by little noradrenergic innervations of cerebral arteries and weak cerebral vasoconstriction. These innervations 
increase with age but decrease by middle-age in a murine model. However, the norepinephrine evoked cerebral vasoconstriction is stronger in mature and middle-aged rats and although the NO would limit the vasoconstriction, this is followed subsequently by a drop in cerebral blood flow [ 34]. Interestingly, previous studies conducted in a murine model suggest that a decreased blood flow is paralleled by a decline in cognitive tasks [ 35-37]. Therefore, one may speculate that a decrease in blood flow would lead to a decreased energetic support for neurons which complicates the functional profile of the aging brain including the post-stroke angiogenesis. The most important changes in vascularization with ageing in the brain are represented in Figure 1 .

\title{
Figure 1
}

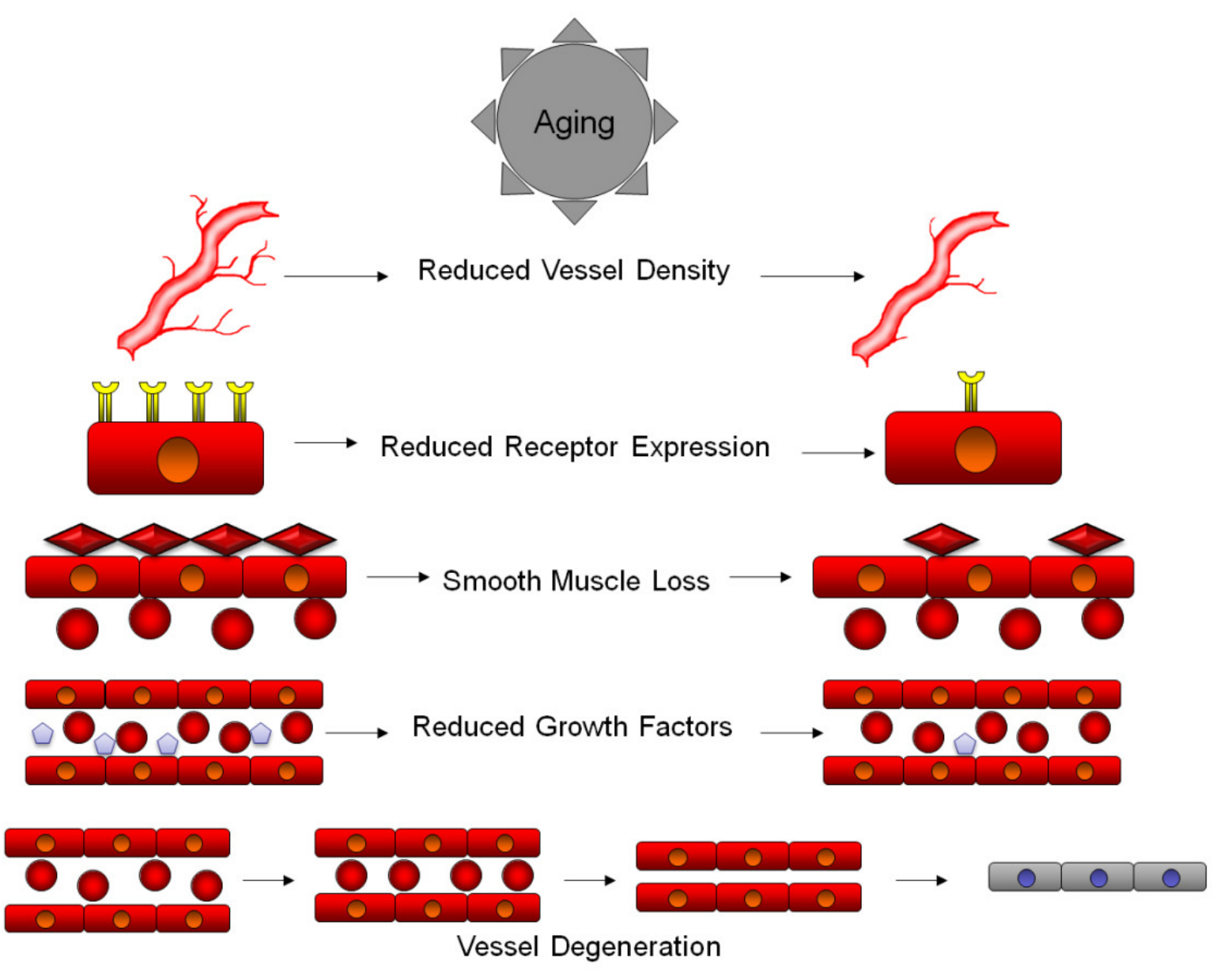

\begin{abstract}
Aging produces a number of physical and biochemical changes in the vascular system that contribute to the age related degeneration of the brain. At the macroscopic level, reduced vessel density is observed in aging brains, leading to an overall reduced blood flow and oxygenation into brain tissue, that may be further exacerbated by pathological factors. At the cellular level, the vessel walls begin to reduce the expression of growth factor receptors, leading to reduced ability to respond to growth and survival factors. Vessels also begin to lose smooth muscle cells, reducing the capacity of vessels to maintain blood pressure, reducing oxygenation in certain circumstances. Aging also leads to a reduced expression of growth and survival factors into the bloodstream, further reducing the survival capacity of vessel lining cells. Many of these factors combine to lead to vessel degeneration, where reduced flow rates, reduced receptor expression and reduced growth factors lead to narrowing of vessels, further reducing flow and reducing vessel diameter, to a point where red blood cells can no longer flow through vessels, leading to loss of oxygenation of tissues and further degeneration into a string vessel state.
\end{abstract}

In addition, old age is characterized by the presence of several pathological entities affecting the vasculature. Cerebral atherosclerosis and small vessel disease are characterized by plasma protein infusion into the vessel wall, accumulation of foamy cells, and fibrosis while another relatively common condition, amyloid angiopathy, is associated with deposition of amyloid in the vessel wall [ 38]. Therefore, since the functionality of the nervous system is dependent upon a well developed and maintained blood supply, we could speculate that any morphological and physiological aging-related changes in the microvasculature could affect neuronal integrity. Related to Alzheimer's disease which is also seen in old-age patient, clinical studies have indicated that education has a protective effect. This has been attributed to a 
"reservoir effect", with the loss of neurons compensated for by more extensive neural connections. Given the links between dementias and reduced blood flow to the brain, it is possible that at least some of this effect may be mediated through a more developed vascular system, or potentially by retention of more juvenile modes of angiogenic response due to extended learning. This would make some sense in the context of experimental studies conducted in rats, which show that angiogenesis occurs in the adult rat cerebellum after physical exercise and motor skills learning [39].

A brief account of central nervous system "normal" senescence and the pathological changes associated with it is presented in Figure 2.

\section{Figure 2}

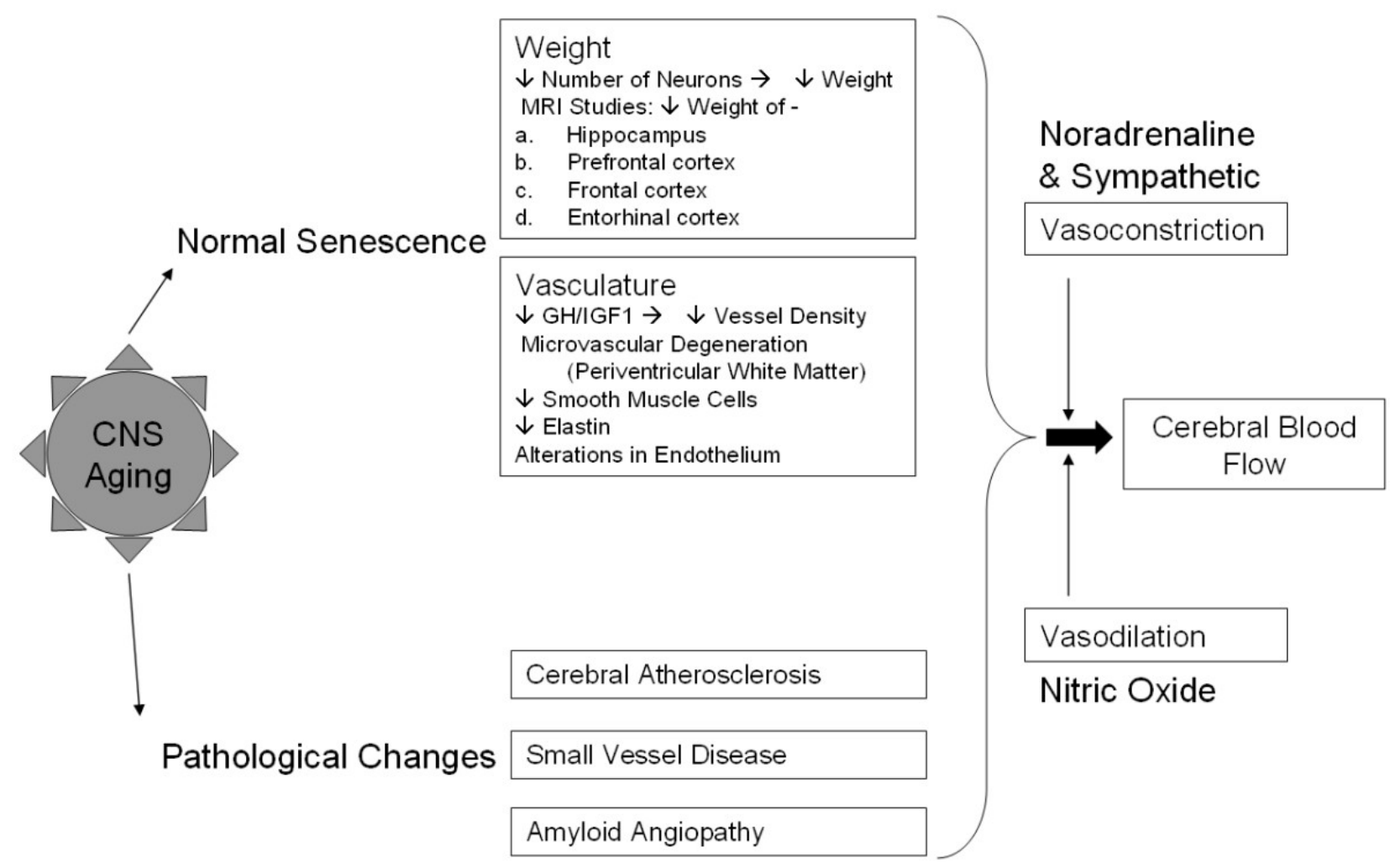

Central nervous system "normal" senescence and pathological changes. Aging in the CNS involves a range of diverse changes, including those associated with normal senescence and present in all surveyed brains. These include reduced weight of brain as a result of decreased neuron counts, as well as reduced vessel density and integrity in the vasculature. More pathological changes include atherosclerosis, small vessel disease and amyloid proteins. These combine with normal vasoconstriction and dilation effects to alter overall cerebral blood flow.

\section{Post-stroke angiogenesis}

One may define the process of angiogenesis as sprouting of new capillaries from pre-existent vessels. As a result of this ongoing process, the newly formed plexus increases gradually in size and remodels into a vascular network which ultimately forms endothelial-cell (EC) channels in close proximity with pericytes and smooth muscle cells. This cellular composition is of paramount importance for functionality of the new vessels including the strength of the wall and regulation of the blood flow [ 40]. Interestingly after stroke, neuroblasts which will further differentiate into fully functional neurons were identified in close proximity around the immature newly created vascular network [41]. This would suggest that neurogenesis depends on a preliminary angiogenesis.

Post-stroke cerebral angiogenesis represents an essential event of crucial importance that unfortunately is not completely understood. Several factors such as: beta-catenin, matrix metalloproteinase-2 (MMP-2) matrix metalloproteinase-9 (MMP-9), tissue inhibitor of matrix metalloproteinase-1 (TIMP-1), hepatocyte growth factor-alpha (HGF-alpha), monocyte chemoatractant protein-1 (MCP-1) and Angiopoietin1/Tie-2 as well as c-kit are increased after ischemic stroke [42]. 
Beta-catenin is a member of the cadherin complex and a signaling protein in the Wnt pathway. It has been linked to the proliferation of neuronal progenitor cells in stroke induced neurogenesis [ 43]. In stroke, MCP-1 is thought to be one of the major factors influencing infiltration of the infarct region by leukocytes and is linked with increased volume of the infarct and increased damage [ 44]. Experimental data suggests that in rats with middle cerebral artery occlusion the lack of MCP-1 or its receptor CCR-2 is associated with a significant decrease in the number of migrating neuroblasts reaching the ischemic area. This affects the neural regeneration negatively [ 45]

The MMP family participates in the breakdown of various extracellular matrix proteins, and is associated with wound healing and tissue remodeling. In stroke, the MMPs have been implicated in the breakdown of the blood-brain barrier and increased damage [ 46- 51]. Different MMPs are expressed in different conditions and at different times following stroke, with MMP-2 being amongst the first activated, followed by MMP-9 in later stages of inflammation and repair [ 52].

Research conducted in murines recently, indicates that the major source of MMP-9 in cerebral ischemia is represented by bone-marrow derived cells [ 53]. Remarkably, MMP-9 promotes neural progenitor cells migration towards the ischemic brain area in a model of transgenic mice after photothrombotic ischemia [ 54].

Clinical studies conducted in patients with various types of stroke have revealed that MMP-2 gene is associated with the development of lacunar stroke [ 55]. However, it rises in parallel with MMP-9 in a rat model of transient cerebral ischemia [ 56]. It seems that MMP-2 and MMP-9 expression is decreased after minocycline administration in rats with induced cerebral ischemia. This is associated with a decreased incidence of hemorrhage and decreased degradation of collagen IV and laminin alpha in the brain. Overall, the neurological outcome in cerebral ischemia is improved by minocycline through MMP-2 and MMP-9 downregulation[ 57]. In patients with severe stroke both MMP-2 and MMP-9 have a strong association with edema formation and midline shift [ 58].

The TIMPs are inhibitors of the MMPs and their induced overexpression has been shown to aid in reduction of infarct size and recovery in a rat model of ischemia [59].

HGF-alpha is known to induce angiogenesis and has been seen to increase in expression following MCAO in mouse models, though a high serum level of the protein was found to be an independent risk factor for stroke in postmenopausal women [ 60,61].

Experimental evidence suggests that angiopoietin 1 (Ang1) and its endothelial kinase 2 (Tie2) are upregulated after stroke by a nitric oxide donor and subsequently promote neuroblast cell migration towards the ischemic area [ 62]. Inceased levels of Ang 1/Tie2 have been recorded in ischemic stroke models after simvastatin treatment and infusion of bone marrow stromal cells. Both treatments result ultimately in vascular stabilization and angiogenesis [ 63, 64].

The above mentioned factors are involved in events of paramount importance namely, endothelial cell migration, tissue remodeling, differentiation and tube-formation, vessel stabilization and stem cell homing mechanisms in areas of revascularization. Therefore, we could speculate that therapy modulating their expression and the activity of these factors could help the recovery and restoration of the damage after stroke [ 42]. Several of these factors are also associated with arteriogenesis, and it is possible that multiple systems may come into play after stroke, depending on its severity, or that there is a certain amount of cross-talk between the angiogenic and arteriogenic systems. A concise summary of the possible molecular mechanisms and general effects of angiogenesis after stroke in elderly subjects is presented in Figure 3 .

\section{Figure 3}




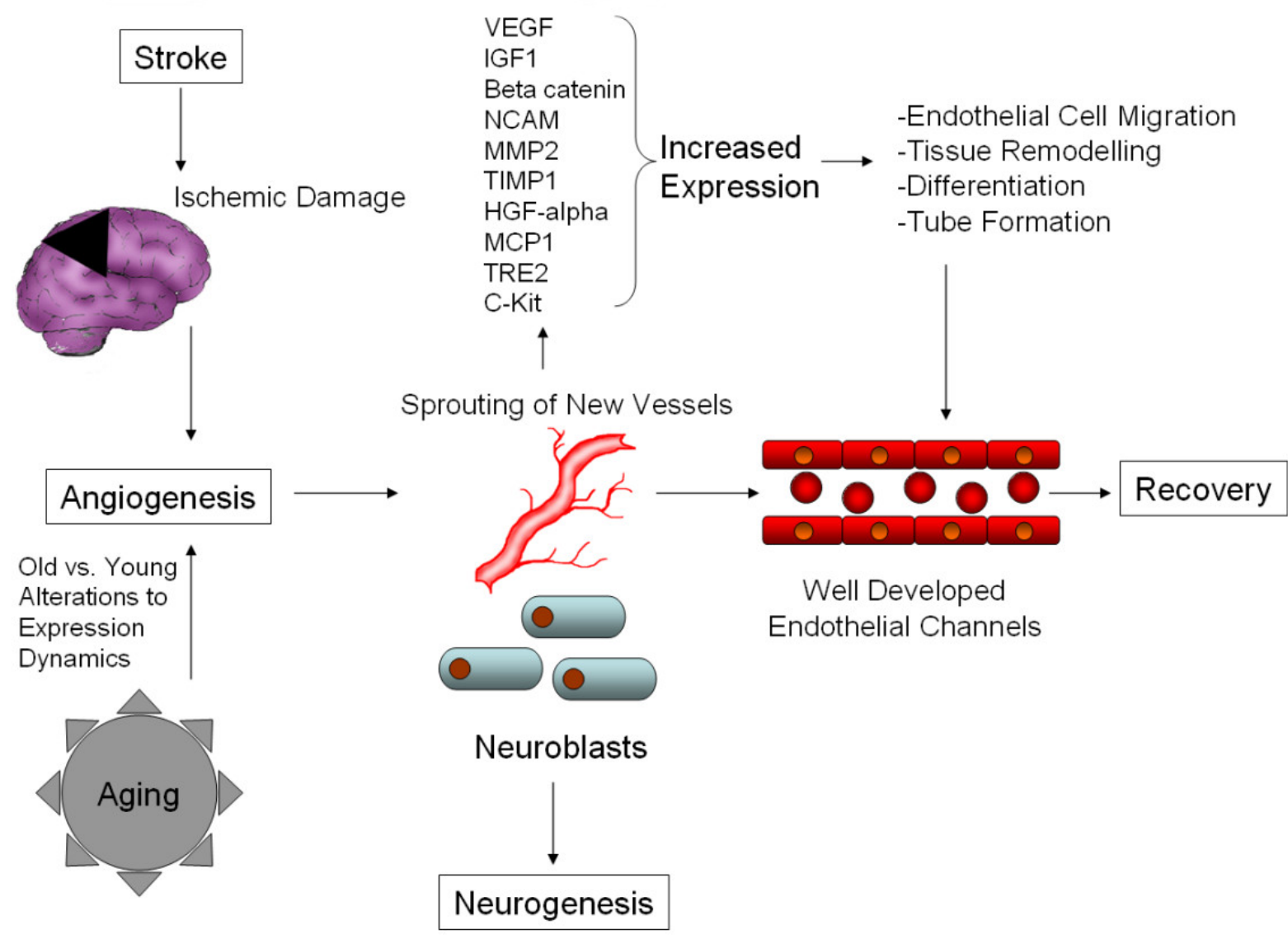

Possible molecular mechanisms and general effects of angiogenesis after stroke in elderly subjects. Stroke causes ischemic damage to the brain, activating angiogeneic mechanisms in response. The degree of response is modulated by changes to the neural and vascular response caused by aging, but the general response remains similar. Growth factors, tissue remodeling and inflammatory proteins are released, leading to the building of new, well developed endothelial channels, which aid recovery.

However, at the present time, we do not have any information on the dynamics of the above mentioned factors with aging. Since ischemic stroke is most likely to be encountered in elderly, any possible therapy should be verified in the context of aging. This means taking into consideration the level of the targeted factors in old age, the ability of the vascular and support systems to respond to them and the integrity of downstream gene expression in the targeted pathways. To date, only VEGF and IGF-1 have been evaluated as modulators of neovascularisation in old subjects.

\section{Post-stroke angiogenesis modulators in old age subjects}

\section{In conclusion}

Old age is associated with a variety of morphological, physiological and metabolic features which may alter recovery after stroke. These features combine normal aging of brain with the ongoing processes of neurodegeneration and small vessel disease. These work in synergy to reduce the capacity of both neural and vascular cells to respond to ischaemic insult, as well as compromising their maintenance and basic functions.

One of the most important changes is represented by a decrease of the normal cerebral vascular network. This may affect the ability of the old-age subjects to mount an adequate pro-angiogenic response after an insult such as stroke. VEGF/VEGFR and IGF-1 represent the most important modulators of post ischemic angiogenesis. Research is showing that some of the changes to the mechanisms behind these effects are similar in both neural and vascular tissues. However, we cannot be sure if the decrease in their level is due to morphological, physiopathological or metabolic changes, or how these may interact to contribute to the changes seen in the aging brain and vasculature. The role and the promoters of these factors are also incompletely understood, but they may be related to age-associated loss of cellular proliferative ability and increasing negative regulation by cellular senescence markers. In addition, since ischemic stroke is a pathological entity most likely encountered in the elderly, future studies should evaluate any possible therapeutic targets related to post ischemic stroke angiogenesis only in aged animals or higher passage in vitro systems. More research is also needed to fully explain the mechanisms at work in the ischemic 
senescent brain which may influence angiogenesis and/or the final outcome of the subject. This is crucial not only to understand the nature of stroke, but also to provide the best therapeutic response with current methods and to develop new treatment and, potentially, preventative options.

\section{Authors' information}

EBP, MD, MHSc (Pharmacology), PhD (Neurobiology) is an academic anatomic pathologist, currently Senior Lecturer with training and experience in Neurobiology research focusing on molecular mechanisms of recovery after ischemic stroke. He conducts a newly created neurobiology research group at his institution.RAS, BSc (Hons), $\mathrm{PhD}$ (Mol Biology) is a scientist conducting angiogenesis research. Particularly he is interested in molecular factors modulating angiogenesis in various settings such as stroke and cancer. He is a Post-Doctoral Fellow and co-supervises several graduate students.RIM, MD, $\mathrm{PhD}$ (Neurorehabilitation) is an academic physician with special interests in research in Neuroanatomy and Neurorehabilitation after stroke including the potential role of modulators of angiogenesis in this pathological entity. She is the head of her department where she currently works.MMO, MD, PhD (Cardiology) is an academic physician interested in angiogenesis modulation in several pathological entities including atherosclerotic ischemic stroke and cardiovascular disease. She is the section head in her academic institution.

\section{Declarations}

\section{Authors' original submitted files for images}

Below are the links to the authors' original submitted files for images.

Authors' original file for figure 1

Authors' original file for figure 2

Authors' original file for figure 3

Authors' original file for figure 4

\section{Competing interests}

In the past five years, the authors of this article have not received reimbursements, fees, funding, or salary from an organization that may in any way gain or lose financially from the publication of this manuscript, either now or in the future.

\section{Authors' contributions}

EBP has made substantial contributions to conception, design, and interpretation of data for this study including the drafting of the manuscript and revising it critically for important intellectual content and has given the final approval for the version to be published.

\section{References}

1. Petcu EB, Sfredel V, Platt D, Herndon JG, Kessler C. Popa-Wagner A Cellular and molecular events underlying the dysregulated response of the aged brain to stroke: a mini-review. Gerontology. 2008;54:6-17.

View Article Google Scholar

2. Petcu EB, Kocher T, Kuhr A, Buga AM, Klöting I, Herndon JG, Kessler C, Popa-Wagner A. Mild systemic inflammation has a neuroprotective effect after stroke in rats. Curr Neurovasc Res. 2008;5:214-23.

View Article Google Scholar

3. Popa-Wagner A, Pirici D, Petcu EB, Mogoanta L, Buga AM, Rosen CL, Leon R, Huber J.

Pathophysiology of the vascular wall and its relevance for cerebrovascular disorders in 
aged rodents. Curr Neurovasc Res. 2010;7:251-67.

View Article Google Scholar

4. Graham SH, Chen J. Programmed cell death in cerebral ischemia. J Cereb Blood Flow Metab. 2001;21:99-109.

View Article Google Scholar

5. Flamme I, Frölich T, Risau W. Molecular mechanisms of vasculogenesis and embryonic angiogenesis. J Cell Physiol. 1997;173:206-10.

View Article Google Scholar

6. Marti HJ Bernaudin M Bellail A Schoch H Euler M Petit E Risau W Hypoxia-induced vascular endothelial growth factor expression precedes neovascularization after cerebral ischemia Am J Pathol 20001563965761876841

7. Yamashita T, Ninomiya M, Hernández Acosta P, García-Verdugo JM, Sunabori T, Sakaguchi M, Adachi K, Kojima T, Hirota Y, Kawase T, Araki N, Abe K, Okano H, Sawamoto K. Subventricular zone-derived neuroblasts migrate and differentiate into mature neurons in the post-stroke adult striatum. J Neurosci. 2006;26:6627-36.

View Article Google Scholar

8. Kokaia Z, Thored P, Arvidsson A, Lindvall O. Regulation of stroke-induced neurogenesis in adult brain--recent scientific progress. Cereb Cortex. 2006;16:i162-7.

View Article Google Scholar

9. Thored P, Wood J, Arvidsson A, Cammenga J, Kokaia Z, Lindvall O. Long-term neuroblast migration along blood vessels in an area with transient angiogenesis and increased vascularization after stroke. Stroke. 2007;38:3032-9.

View Article Google Scholar

10. Plate KH, Beck H, Danner S, Allegrini PR, Wiessner C. Cell type specific upregulation of vascular endothelial growth factor in an MCA-occlusion model of cerebral infarct. J Neuropathol Exp Neurol. 1999;58:654-66.

View Article Google Scholar

11. Slevin M Krupinski J Rovira N Turu M Luque A Baldellou M Sanfeliu C de Vera N Badimon L Identification of pro-angiogenic markers in blood vessels from stroked-affected brain tissue using laser-capture microdissection BMC Genomics 2009101132664824

12. Brody H. Organization of the cerebral cortex. III. A study of aging in the human cerebral cortex. J Comp Neurol. 1955;102:511-6.

View Article Google Scholar

13. Jernigan TL, Archibald SL, Fennema-Notestine C, Gamst AC, Stout JC, Bonner J, Hesselink JR. Effects of age on tissues and regions of the cerebrum and cerebellum. Neurobiol Aging. 2001;22:581-94.

View Article Google Scholar

14. Miyahira Y, Yu J, Hiramatsu K, Shimazaki Y, Takeda Y. Brain volumetric MRI study in healthy elderly persons using statistical parametric mapping. Seishin Shinkeigaku Zasshi.

2004;106:138-51.

View Article Google Scholar

15. Curiati PK, Tamashiro JH, Squarzoni P, Duran FL, Santos LC, Wajngarten M, Leite CC, Vallada H, Menezes PR, Scazufca M, Busatto GF, Alves TC. Brain structural variability due to aging and gender in cognitively healthy Elders: results from the Sao Paulo Ageing and Health study. Am J Neuroradiol. 2009;30:1850-6. 
16. Pakkenberg B, Gundersen HJ, Mortensen EL, Lauritzen MJ, Jeune B, Regeur L, West MJ, Schwartz TW. The normal brain: a new knowledge in different fields. Ugeskr Laeger. 1997;159:723-7.

View Article Google Scholar

17. Merrill DA, Roberts JA, Tuszynski MH. Conservation of neuron number and size in entorhinal cortex layers II, III, and V/VI of aged primates. J Comp Neurol. 2000;422:396-401.

View Article Google Scholar

18. Walter J, Keiner S, Witte OW, Redecker C. . Differential stroke-induced proliferative response of distinct precursor cell subpopulations in the young and aged dentate gyrus Neuroscience. 2010;:1279-86.

View Article Google Scholar

19. Knox CA, Oliveira A. Brain aging in normotensive and hypertensive strains of rats III. A quantitative study of cerebrovasculature. Acta Neuropathol. 1980;52:17-25.

View Article Google Scholar

20. Meier-Ruge W, Hunziker O, Schulz U, Tobler HJ, Schweizer A. Stereological changes in the capillary network and nerve cells of the aging human brain. Mech Ageing Dev. 1980;14:23343.

View Article Google Scholar

21. Sonntag WE, Lynch CD, Cooney PT, Hutchins PM. Decreases in cerebral microvasculature with age are associated with the decline in growth hormone and insulin-like growth factor 1. Endocrinology. 1997;138:3515-20.

View Article Google Scholar

22. Hughes CC, Lantos PL. A morphometric study of blood vessel, neuron and glial cell distribution in young and old rat brain. J Neurol Sci. 1987;79:101-10.

View Article Google Scholar

23. Amenta F, Ferrante F, Mancini M, Sabbatini M, Vega JA, Zaccheo D. Effect of long-term treatment with the dihydropyridine-type calcium channel blocker darodipine (PY 108-068) on the cerebral capillary network in aged rats. Mech Ageing Dev. 1995;78:27-37.

View Article Google Scholar

24. Ingraham JP, Forbes ME, Riddle DR, Sonntag WE. Aging reduces hypoxia-induced microvascular growth in the rodent hippocampus. J Gerontol A Biol Sci Med Sci. 2008;63:1220.

View Article Google Scholar

25. Farkas E, de Vos RA, Donka G, Jansen Steur EN, Mihály A, Luiten PG. Age-related microvascular degeneration in the human cerebral periventricular white matter. Acta Neuropathol. 2006;111:150-7.

View Article Google Scholar

26. Hajdu MA, Heistad DD, Siems JE, Baumbach GL. Effects of aging on mechanics and composition of cerebral arterioles in rats. Circ Res. 1990;66:1747-54.

View Article Google Scholar

27. de Jong GI, Traber J, Luiten PG. Formation of cerebrovascular anomalies in the ageing rat is delayed by chronic nimodipine application. Mech Ageing Dev. 1992;64:255-72.

View Article Google Scholar 
28. Keuker JI, Luiten PG, Fuchs E. Capillary changes in hippocampal CA1 and CA3 areas of the aging rhesus monkey. Acta Neuropathol. 2000;100:665-72.

View Article Google Scholar

29. Farkas E, Luiten PG. Cerebral microvascular pathology in aging and Alzheimer's disease. Prog Neurobiol. 2001;64:575-611.

View Article Google Scholar

30. Shah GN, Mooradian AD. Age-related changes in the blood-brain barrier. Exp Gerontol. 1997;32:501-19.

View Article Google Scholar

31. Farkas E, De Jong GI, Apró E, Keuker JI, Luiten PG. Calcium antagonists decrease capillary wall damage in aging hypertensive rat brain. Neurobiol Aging. 2001;22:299-309.

View Article Google Scholar

32. Zhang Y, Peng YY, Chen GY, Chen WF. Cerebral blood flow, cerebral blood volume, oxygen utilization and oxygen extraction fraction: the influence of age. Nan Fang Yi Ke Da Xue Xue Bao. 2010;30:1237-9.

View Article Google Scholar

33. Gjedde A, Diemer NH. Double-tracer study of the fine regional blood-brain glucose transfer in the rat by computer-assisted autoradiography. J Cereb Blood Flow Metab. 1985;5:282-9.

View Article Google Scholar

34. Omar NM, Marshall JM. Age-related changes in sympathetic innervation of cerebral vessels and in carotid vascular responses to norepinephrine: in vitro and in vivo studies. $\mathrm{J}$ Appl Physiol. 2010;109:314-22.

View Article Google Scholar

35. Goldman H, Berman RF, Gershon S, Murphy SL, Altman HJ. Correlation of behavioral and cerebrovascular functions in the aging rat. Neurobiol Aging. 1987;8:409-16.

View Article Google Scholar

36. Goldman H, Berman RF, Gershon S, Murphy S, Morehead M, Altman HJ. Cerebrovascular permeability and cognition in the aging rat. Neurobiol Aging. 1992;13:57-62.

View Article Google Scholar

37. Berman RF, Goldman H, Altman HJ. Age-related changes in regional cerebral blood flow and behavior in Sprague-Dawley rats. Neurobiol Aging. 1988;9:691-6.

View Article Google Scholar

38. Grinberg LT Thal DR Vascular pathology in the aged human brain Acta Neuropathol 2010 11932772902831184

39. Isaacs KR, Anderson BJ, Alcantara AA, Black JE, Greenough WT. Exercise and the brain: angiogenesis in the adult rat cerebellum after vigorous physical activity and motor skill learning. J Cereb Blood Flow Metab. 1992;12:110-9.

View Article Google Scholar

40. Carmeliet P. Angiogenesis in life, disease and medicine. Nature. 2005;438:932-6.

View Article Google Scholar

41. Yamashita T, Ninomiya M, Hernández Acosta P, García-Verdugo JM, Sunabori T, Sakaguchi M, Adachi K, Kojima T, Hirota Y, Kawase T, Araki N, Abe K, Okano H, Sawamoto K. Subventricular 
zone-derived neuroblasts migrate and differentiate into mature neurons in the post-stroke adult striatum. J Neurosci. 2006;26:6627-36.

View Article Google Scholar

42. Slevin M Krupinski J Badimon L Controlling the angiogenic switch in developing atherosclerotic plaques: possible targets for therapeutic intervention J Angiogenes Res 2009142776234

43. Lei ZN, Zhang LM, Sun FY. Beta-catenin siRNA inhibits ischemia-induced striatal neurogenesis in adult rat brain following a transient middle cerebral artery occlusion. Neurosci Lett. 2008;435:108-12.

View Article Google Scholar

44. Conductier G, Blondeau N, Guyon A, Nahon JL, Rovère C. The role of monocyte chemoattractant protein MCP1/CCL2 in neuroinflammatory diseases. J Neuroimmunol. 2010;224:93-100.

View Article Google Scholar

45. Sakurai-Yamashita Y, Shigematsu K, Yamashita K, Niwa M. Expression of MCP-1 in the hippocampus of SHRSP with ischemia-related delayed neuronal death. Cell Mol Neurobiol. 2006;26:823-31.

View Article Google Scholar

46. Qiu J Xu J Zheng Y Wei Y Zhu X Lo EH Moskowitz MA Sims JR High-Mobility Group Box 1 Promotes Metalloproteinase-9 upregulation Through Toll-Like Receptor 4 After Cerebral Ischemia Stroke 20104192077823066477

47. Kurzepa J, Bielewicz J, Grabarska A, Stelmasiak Z, Stryjecka-Zimmer M, Bartosik-Psujek H. Matrix metalloproteinase- 9 contributes to the increase of tau protein in serum during acute ischemic stroke. J Clin Neurosci. 2010;17:997-9.

View Article Google Scholar

48. Dong X Song YN Liu WG Guo XL Curr Neuropharmacol 200974269752811860

49. Suzuki Y. Mmp-9, a potential target for cerebral ischemic treatment. Role of tissue-type plasminogen activator in ischemic stroke. J Pharmacol Sci. 2010;113:203-7.

View Article Google Scholar

50. Jin R Yang G Li G Molecular insights and therapeutic targets for blood-brain barrier disruption in ischemic stroke: critical role of matrix metalloproteinases and tissue-type plasminogen activator Neurobiol Dis 2010383376852862862

51. Bäck M, Ketelhuth DF, Agewall S. Matrix metalloproteinases in atherothrombosis. Prog Cardiovasc Dis. 2010;52:410-28.

View Article Google Scholar

52. Rosenberg GA. Matrix metalloproteinases in neuroinflammation. Glia. 2002;39:279-91. View Article Google Scholar

53. Wang G Guo Q Hossain M Fazio V Zeynalov E Janigro D Mayberg MR Namura S Bone marrow-derived cells are the major source of MMP-9 contributing to blood-brain barrier dysfunction and infarct formation after ischemic stroke in mice Brain Res 20091294183 922758551

54. Kang SS, Kook JH, Hwang S, Park SH, Nam SC, Kim JK. Inhibition of matrix metalloproteinase- 9 attenuated neural progenitor cell migration after photothrombotic 
ischemia. Brain Res. 2008;1228:20-6.

View Article Google Scholar

55. Fatar M, Stroick M, Steffens M, Senn E, Reuter B, Bukow S, Griebe M, Alonso A, Lichtner P, Bugert P, Meitinger T, Wienker TF, Hennerici MG. Single-nucleotide polymorphisms of MMP2 gene in stroke subtypes. Cerebrovasc Dis. 2008;26:113-9.

View Article Google Scholar

56. Liu R Liu Q He S Simpkins JW Yang SH Combination therapy of 17beta-estradiol and recombinant tissue plasminogen activator for experimental ischemic stroke $\mathrm{J}$ Pharmacol Exp Ther 201033231006122835431

57. Machado LS Sazonova IY Kozak A Wiley DC El-Remessy AB Ergul A Hess DC Waller JL Fagan SC Minocycline and tissue-type plasminogen activator for stroke: assessment of interaction potential Stroke 20094093028332754038

58. Horstmann S, Koziol JA, Martinez-Torres F, Nagel S, Gardner H, Wagner S. Correlation with intracranial pressure and matrix metalloproteinase 2 and 9 expression. J Neurol Sci. 2009;276:75-8.

View Article Google Scholar

59. Baker AH Sica V Work LM Williams-Ignarro S de Nigris F Lerman LO Casamassimi A Lanza A Schiano C Rienzo M Ignarro LJ Napoli CL Brain protection using autologous bone marrow cell, metalloproteinase inhibitors, and metabolic treatment in cerebral ischemia Proc Natl Acad Sci USA 2007104935976021805552

60. Rajpathak SN Wang T Wassertheil-Smoller S Strickler HD Kaplan RC McGinn AP Wildman RP Rosenbaum D Rohan TE Scherer PE Cushman M Ho GY Hepatocyte growth factor and the risk of ischemic stroke developing among postmenopausal women: results from the Women's Health Initiative Stroke 2010415857623903044

61. Nagayama T, Nagayama M, Kohara S, Kamiguchi H, Shibuya M, Katoh Y, Itoh J, Shinohara Y. Post-ischemic delayed expression of hepatocyte growth factor and c-Met in mouse brain following focal cerebral ischemia. Brain Res. 2004;999:155-66.

View Article Google Scholar

62. Cui X Chen J Zacharek A Roberts C Yang Y Chopp M Nitric oxide donor up-regulation of SDF1/CXCR4 and Ang1/Tie2 promotes neuroblast cell migration after stroke J Neurosci Res 200987186952606920

63. Chen J Cui X Zacharek A Chopp M Increasing Ang1/Tie2 expression by simvastatin treatment induces vascular stabilization and neuroblast migration after stroke J Cell Mol Med 20091371348573710660

64. Zacharek A Chen J Cui X Li A Li Y Roberts C Feng Y Gao Q Chopp M Angiopoietin1/Tie2 and VEGF/Flk1 induced by MSC treatment amplifies angiogenesis and vascular stabilization after stroke J Cereb Blood Flow Metab 200727101684912796470

65. Rosenstein JM, Krum JM. New roles for VEGF in nervous tissue--beyond blood vessels. Exp Neurol. 2004;187:246-53.

View Article Google Scholar

66. Brown WR A review of string vessels or collapsed, empty basement membrane tubes $\mathbf{J}$ Alzheimers Dis 2010213725393081641

67. Palmer TD, Willhoite AR, Gage FH. Vascular niche for adult hippocampal neurogenesis. J Comp Neurol. 2000;425:479-94. 
68. Sun Y Jin K Xie L Childs J Mao XO Logvinova A Greenberg DA VEGF-induced neuroprotection, neurogenesis, and angiogenesis after focal cerebral ischemia J Clin Invest 200311112184351161428

69. Jin K Zhu Y Sun Y Mao XO Xie L Greenberg DA Vascular endothelial growth factor (VEGF) stimulates neurogenesis in vitro and in vivo Proc Natl Acad Sci USA 20029918 1194650129374

70. Plate KH, Beck H, Danner S, Allegrini PR, Wiessner C. Cell type specific upregulation of vascular endothelial growth factor in an MCA-occlusion model of cerebral infarct. J Neuropathol Exp Neurol. 1999;58:654-66.

View Article Google Scholar

71. Mesri M Morales-Ruiz M Ackermann EJ Bennett CF Pober JS Sessa WC Altieri DC Suppression of vascular endothelial growth factor-mediated endothelial cell protection by survivin targeting Am J Pathol 200115851757651891951

72. Issa R, Krupinski J, Bujny T, Kumar S, Kaluza J, Kumar P. Vascular endothelial growth factor and its receptor, KDR, in human brain tissue after ischemic stroke. Lab Invest. 1999;79:41725.

View Article Google Scholar

73. Slevin M, Krupinski J, Slowik A, Kumar P, Szczudlik A, Gaffney J. Serial measurement of vascular endothelial growth factor and transforming growth factor-beta1 in serum of patients with acute ischemic stroke. Stroke. 2000;31:1863-70.

View Article Google Scholar

74. Turu MM Slevin M Matou S West D Rodríguez C Luque A Grau-Olivares M Badimon L Martinez-Gonzalez J Krupinski J C-reactive protein exerts angiogenic effects on vascular endothelial cells and modulates associated signalling pathways and gene expression BMC Cell Biol 20089472551596

75. Bello G, Cailotto F, Hanriot D, Kolopp-Sarda MN, Latger-Cannard V, Hess K, Zannad F, Longrois D. Ropars C-reactive protein (CRP) increases VEGF-A expression in monocytic cells via a PI3-kinase and ERK 1/2 signaling dependent pathway. Atherosclerosis. 2008;200:286-93.

View Article Google Scholar

76. Shweiki D, Itin A, Soffer D, Keshet E. Vascular endothelial growth factor induced by hypoxia may mediate hypoxia-initiated angiogenesis. Nature. 1992;359:843-5.

View Article Google Scholar

77. LaManna JC, Kuo NT, Lust WD. Hypoxia-induced brain angiogenesis. Signals and consequences. Adv Exp Med Biol. 1998;454:287-93.

View Article Google Scholar

78. Marti HJ Bernaudin M Bellail A Schoch H Euler M Petit E Risau W Hypoxia-induced vascular endothelial growth factor expression precedes neovascularization after cerebral ischemia Am J Pathol 20001563965761876841

79. Hoehn BD, Harik SI, Hudetz AG. VEGF mRNA expressed in microvessels of neonatal and adult rat cerebral cortex. Brain Res Mol Brain Res. 2002;101:103-8. 
80. Emerich DF, Schneider P, Bintz B, Hudak J, Thanos CG. Aging reduces the neuroprotective capacity, VEGF secretion, and metabolic activity of rat choroid plexus epithelial cells. Cell Transplant. 2007;16:697-705.

View Article Google Scholar

81. Gao P Shen F Gabriel RA Law D Yang E Yang GY Young WL Su H Attenuation of brain response to vascular endothelial growth factor-mediated angiogenesis and neurogenesis in aged mice Stroke 2009401135966002783321

82. Beck H, Acker T, Püschel AW, Fujisawa H, Carmeliet P, Plate KH. Cell type-specific expression of neuropilins in an MCA-occlusion model in mice suggests a potential role in postischemic brain remodeling. J Neuropathol Exp Neurol. 2002;61:339-50.

View Article Google Scholar

83. Fuh G, Garcia KC, de Vos AM. The interaction of neuropilin-1 with vascular endothelial growth factor and its receptor flt-1. J Biol Chem. 2000;275:26690-5.

View Article Google Scholar

84. Gluzman-Poltorak Z, Cohen T, Shibuya M, Neufeld G. Vascular endothelial growth factor receptor-1 and neuropilin-2 form complexes. J Biol Chem. 2001;276:18688-94.

View Article Google Scholar

85. Punglia RS, Lu M, Hsu J, Kuroki M, Tolentino MJ, Keough K, Levy AP, Levy NS, Goldberg MA, D'Amato RJ, Adamis AP. Regulation of vascular endothelial growth factor expression by insulin-like growth factor I. Diabetes. 1997;46:1619-26.

View Article Google Scholar

86. Anderson MF, Aberg MA, Nilsson M, Eriksson PS. Insulin-like growth factor-I and neurogenesis in the adult mammalian brain. Brain Res Dev Brain Res. 2002;134:115-22.

View Article Google Scholar

87. Lichtenwalner RJ, Forbes ME, Bennett SA, Lynch CD, Sonntag WE, Riddle DR.

Intracerebroventricular infusion of insulin-like growth factor-I ameliorates the age-related decline in hippocampal neurogenesis. Neuroscience. 2001;107:603-13.

View Article Google Scholar

88. Sonntag WE, Lynch CD, Bennett SA, Khan AS, Thornton PL, Cooney PT, Ingram RL, McShane T, Brunso-Bechtold JK. Alterations in insulin-like growth factor-1 gene and protein expression and type 1 insulin-like growth factor receptors in the brains of ageing rats. Neuroscience. 1999;88:269-79.

View Article Google Scholar

89. Shetty AK, Hattiangady B, Shetty GA. Stem/progenitor cell proliferation factors FGF-2, IGF1, and VEGF exhibit early decline during the course of aging in the hippocampus: role of astrocytes. Glia. 2005;51:173-86.

View Article Google Scholar

90. Lopez-Lopez C LeRoith D Torres-Aleman I Insulin-like growth factor I is required for vessel remodelling in the adult brain Proc Natl Acad Sci USA 20041012698338470760

91. Schwab S, Spranger M, Krempien S, Hacke W, Bettendorf M. Plasma insulin-like growth factor I and IGF binding protein 3 levels in patients with acute cerebral ischemic injury. Stroke. 1997;28:1744-8.

View Article Google Scholar

92. Denti L, Annoni V, Cattadori E, Salvagnini MA, Visioli S, Merli MF, Corradi F, Ceresini G, Valenti G, Hoffman AR, Ceda GP. Insulin-like growth factor 1 as a predictor of ischemic 
stroke outcome in the elderly. Am J Med. 2004;117:312-7.

View Article Google Scholar

93. Beilharz EJ, Russo VC, Butler G, Baker NL, Connor B, Sirimanne ES, Dragunow M, Werther GA, Gluckman PD, Williams CE, Scheepens A. Co-ordinated and cellular specific induction of the components of the IGF/IGFBP axis in the rat brain following hypoxic-ischemic injury. Brain Res Mol Brain Res. 1998;59:119-34.

View Article Google Scholar

94. Endres M, Piriz J, Gertz K, Harms C, Meisel A, Kronenberg G, Torres-Aleman I. Serum insulinlike growth factor I and ischemic brain injury. Brain Res. 2007;1185:328-35.

View Article Google Scholar

95. Schäbitz WR, Hoffmann TT, Heiland S, Kollmar R, Bardutzky J, Sommer C, Schwab S. Delayed neuroprotective effect of insulin-like growth factor-i after experimental transient focal cerebral ischemia monitored with mri. Stroke. 2001;32:1226-33.

View Article Google Scholar

96. Guan J, Bennet L, Gluckman PD, Gunn AJ. Insulin-like growth factor-1 and post-ischemic brain injury. Prog Neurobiol. 2003;70:443-.

View Article Google Scholar

97. Guan J, Bennet L, George S, Wu D, Waldvogel HJ, Gluckman PD, Faull RL, Crosier PS, Gunn AJ. Insulin-like growth factor-1 reduces postischemic white matter injury in fetal sheep. J Cereb Blood Flow Metab. 2001;21:493-502.

View Article Google Scholar

98. Issa R, AlQteishat A, Mitsios N, Saka M, Krupinski J, Tarkowski E, Gaffney J, Slevin M, Kumar S, Kumar P. Expression of basic fibroblast growth factor mRNA and protein in the human brain following ischaemic stroke. Angiogenesis. 2005;8:53-62.

View Article Google Scholar

99. Jump SS, Childs TE, Zwetsloot KA, Booth FW, Lees SJ. Fibroblast growth factor 2-stimulated proliferation is lower in muscle precursor cells from old rats. Exp Physiol. 2009;94:739-48. View Article Google Scholar

100. Vavken P Saad FA Murray MM Age dependence of expression of growth factor receptors in porcine ACL fibroblasts J Orthop Res 20102881107122892023

101. Boisen L, Drasbek KR, Pedersen AS, Kristensen P. Evaluation of endothelial cell culture as a model system of vascular ageing. Exp Gerontol. 2010;45:779-87.

View Article Google Scholar 